\title{
From Malthus to Ohlin: Trade, Industrialisation and Distribution Since 1500
}

\author{
KEVIN H. O'ROURKE \\ Department of Economics and IIIS, Trinity College, Dublin 2, Ireland, UK and CEPR and NBER
}

JEFFREY G. WILLIAMSON

Department of Economics, Harvard University, Cambridge, MA 02138, USA and NBER

\begin{abstract}
A recent endogenous growth literature has focused on the transition from a Malthusian world where real wages were linked to factor endowments, to one where modern growth has broken that link. In this paper we present evidence on another, related phenomenon: the dramatic reversal in distributional trends - from a steep secular fall to a steep secular rise in wage-land rent ratios - which occurred some time early in the 19th century. What explains this reversal? While it may seem logical to locate the causes in the Industrial Revolutionary forces emphasized by endogenous growth theorists, we provide evidence that something else mattered just as much: the opening up of the European economy to international trade.
\end{abstract}

Keywords: trade, industrial revolution, income distribution

JEL classification: $\mathrm{F} 1, \mathrm{~N} 7, \mathrm{O} 4$

\section{Introduction}

A large literature has emerged over the course of the last decade in which economic theorists (e.g., Goodfriend and McDermott, 1995; Lucas, 1999; Galor and Weil, 2000; Jones, 2001; Hansen and Prescott, 2002) have attempted to model the dramatic structural break in European living standards which occurred at some point between 1750 and 1850. Prior to the structural break real wages and output per capita were relatively stagnant, whereas afterwards they enjoyed a sustained and impressive increase. If the first regime seems consistent with the famous model offered by Malthus (1826), in which living standards depend positively on land-labor ratios, and fertility depends positively on living standards, the second regime is not, since population has continued to increase since the early 19th century.

This paper exploits recently-collected data documenting relative factor price trends over the very long run, and points out that there was another, equally radical structural break which occurred in north-west Europe at about the same 
time as the break in living standards: a dramatic reversal of long run trends in the ratio of wages to land rents. Prior to the 19th century, there had been a long period during which the wage-land rent ratio declined, implying a rise in inequality (since land owners were far closer to the top of the income distribution than were landless workers). This trend was consistent with a Malthusian world in which an increasing population pressed on a quasi-fixed land endowment, to the benefit of landlords (Hanson and Prescott, 2002). At some point in the 19th century this pattern reversed, and wages started to rise relative to land rents, implying a decline in inequality. This more modern trend is inconsistent with a Malthusian world in which wage-rent ratios were determined by the land endowment per worker, since the land-labor ratio continued to decline into the 19th century and beyond. It appears, therefore, that there is more evidence that the traditional link between factor prices and factor endowments was broken some time in the 19th century.

What explains the structural break in wage-rent ratio behavior? An obvious explanation is that it was caused by the same industrial revolutionary forces underlying the break in living standards behavior. Some scholars date the first industrial revolution from 1760, some from 1780, and some refuse to use the phrase at all, but everyone agrees that the rate of technological advance accelerated in English industry about this time (Mokyr, 1990; Crafts, 1994; Temin, 1997). In a specific factors world in which two commodities are produced - agricultural products (using land and labor) and manufactured goods (using capital and labor) - productivity advance in English industry should have drawn workers out of agriculture and into the cities, raising wages, lowering rents, and inflating the ratio of wages to rents.

It is these industrial revolutionary forces that are the focus of the theoretical papers cited earlier, and we do not deny that they were important in explaining the reversal in distributional trends as well. However, we will argue that the reversal can also be explained by a crucial change in the world economy that coincided with the Industrial Revolution: Europe became dramatically more open to trade in the decades following Waterloo. Global market integration could on its own have cut the links between factor prices and domestic land-labor ratios, or at least weakened them dramatically.

It might be objected that intercontinental trade had been on the rise at least since the Voyages of Discovery-growing at around 1 percent per annum between 1500 and 1800 - and thus that trade should have influenced factor prices for several centuries before the structural break occurred. However, it turns out that the growth in European overseas trade was not due to global commodity market integration, as measured by a decline in intercontinental price gaps, but rather to shifts in demand and supply in Europe, Asia and the Americas (O'Rourke and Williamson, 2002a). Presumably the Voyages of Discovery led to a dramatic fall in transport costs, but in the centuries that followed price gaps remained stable, rather than falling continuously. It was only with the combined influence of the switch from mercantilism to free trade in the first half of the 19th century and the appearance of new transport 
technologies and a sustained decline in transport costs over the full century that the big intercontinental price gaps began to evaporate; and crucially it was only in the 19th century that large-scale intercontinental trade became possible in such basic commodities as grain, animal products, coal and manufactured intermediates. It follows that it was only in the 19th century that intercontinental trade began to have the effects on factor prices which were identified by two famous Swedish observers of the period, Eli Heckscher and Bertil Ohlin (Flam and Flanders, 1991). Indeed, in earlier work we have shown that international trade did affect wage-rent ratios in the manner identified by Heckscher-Ohlin theory in the years between 1870 and 1913: trade raised wage-rent ratios in Europe, by lowering the price of imported agricultural products relative to the price of exported manufactured goods; and trade lowered wagerent ratios in the land-abundant periphery, by increasing the price of exported agricultural products relative to the price of imported manufactured goods (O'Rourke and Williamson, 1994, 1999; O'Rourke et al., 1996).

If the first great globalization shock hit the world economy in the early 19th century rather than after 1492, then it follows that European commodity prices (and in particular the ratio of agricultural to industrial prices) should have been determined primarily by domestic supply and demand prior to the early 19th century, while they should have been determined by global supply and demand afterwards. We test this intuition here for one country, England, which was at the heart of the 19th century global economy and which was thus fully exposed to the effects of growing international trade. We ask: at what stage did English commodity prices become decoupled from English factor endowments? What difference did the opening up of the domestic economy to trade make to the long run evolution of relative commodity prices in England? What were the determinants of the wage-rent ratio before the structural break compared with its determinants afterwards? And finally, what were the relative contributions of the industrial revolution and international trade in producing this historic reversal in long-run wage-rent ratio trends?

Our implicit theoretical framework is a traditional static trade model (the specific factors model), with exogenous endowments and technology. Clearly, the world was more complicated than that, and the growth models cited above all reflect this; but the fact that such a simple open economy framework can explain so much is telling in its own way. Section 2 presents the wage-rent ratio evidence, while Section 3 reviews the evidence suggesting that the 19th century was a period of commodity market integration in a way that earlier centuries simply were not. Section 4 presents evidence on how English factor prices were determined in the pre-1750 period, consistent with closed economy theory, and generates predictions as to how wage-rent ratios would have continued to evolve had the structure of the economy remained unchanged. Section 5 compares these predictions with the post-1840 English reality, and attempts to measure the role of industrialization and trade in accounting for the difference between prediction and reality. Section 6 discusses the transition 
which the English economy underwent between 1750 and 1840, and Section 7 concludes.

\section{Wage-Rent Ratios in England Since 1500}

Figure 1 plots our index of wage-land rent ratios in England from 1500 to 1936. The sources used are described in Appendix 1. Briefly, the nominal agricultural wage series is based on recent work by Clark $(2001$, n.d.) for the 16th to the 18th centuries, and on older sources for the 19th and 20th centuries (Fox, Bowley and Wood, both in Mitchell, 1988). The land rent series uses Allen's (1988) South Midlands data until 1831, and Thompson (1907) and Rhee (1949) thereafter. The series shows a large decline in wage-rent ratios between 1500 and about 1850, and a substantial rise thereafter. It is this reversal in distributional trends that we wish to explain.

\section{Global Commodity Market Integration: The 19th Century Was Different}

Since we want to offer an explanation for the rise in wage-rent ratios after 1800 that discriminates between industrialization and trade as potential causes, we need to be precise about exactly when Europe opened up to intercontinental trade in the sorts of goods that might have an effect on European factor prices. We are not primarily concerned with trade in goods like spices or silver, even though all trade should have some sort of an effect on factor prices in general equilibrium; rather, we are concerned with trade in 'competing commodities' such as grain or textiles, which might directly displace European production, and give

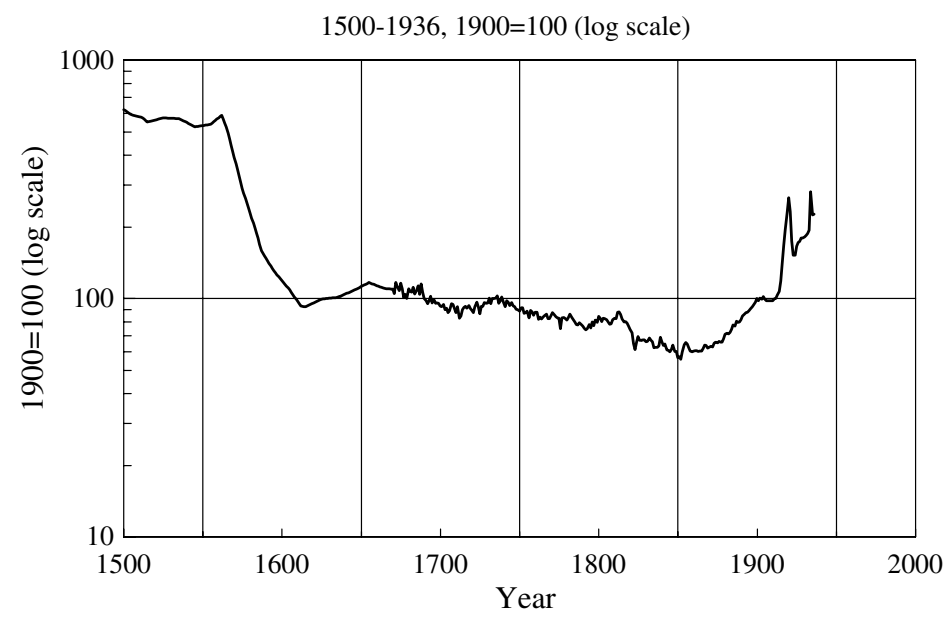

Figure 1. English wage-rental ratio. Source: Appendix 1. 
rise to the large-scale reshuffling of factors between sectors that might alter wages, profits or rents. This section stresses intercontinental trade, since it was the dramatically different factor endowments of the New World that would eventually place European land rents under sustained pressure, and contribute to the reversal in wage-rent ratios. Obviously within Europe there were regions of relative land abundance and relative land scarcity, and the costs of trade between these regions had been declining for several centuries. For example, Jacks (2000) has documented substantial commodity market integration across the North Sea and Baltic Sea between 1500 and 1800. But no amount of trade with Prussia, for example, could have had the same impact on the British economy, or on British factor prices, as trade with the Americas eventually did in the 19th century.

The costs of trading across frontiers will be reflected in price differentials for homogenous goods in different markets, and a decline in these price differentials provides the clearest indication of international commodity market integration. Prior to the 19th century, there is no systematic evidence of inter-continental price convergence. For example, Figure 2 graphs the relationship between the average prices received by the East India Company on its Asian textile sales in Europe, and the average prices it paid for those textiles in Asia. This textile trade was extremely large and it was on the rise. Yet, there is no sign of declining mark-ups (where mark-ups include all trade costs, as well as any East India Company monopoly profits) over the century between 1664 and 1769; trade expansion was due to outward shifts in demand and supply, rather than to commodity market integration (O'Rourke and Williamson, 2002a, b). This is not an isolated finding; indeed, somewhat surprisingly O'Rourke and Williamson (2002b) find no evidence of intercontinental price convergence, over a much longer time period (1580-1800 or so), even for very high-value-to-weight-ratio 'non-competing' commodities such as cloves, pepper and coffee.

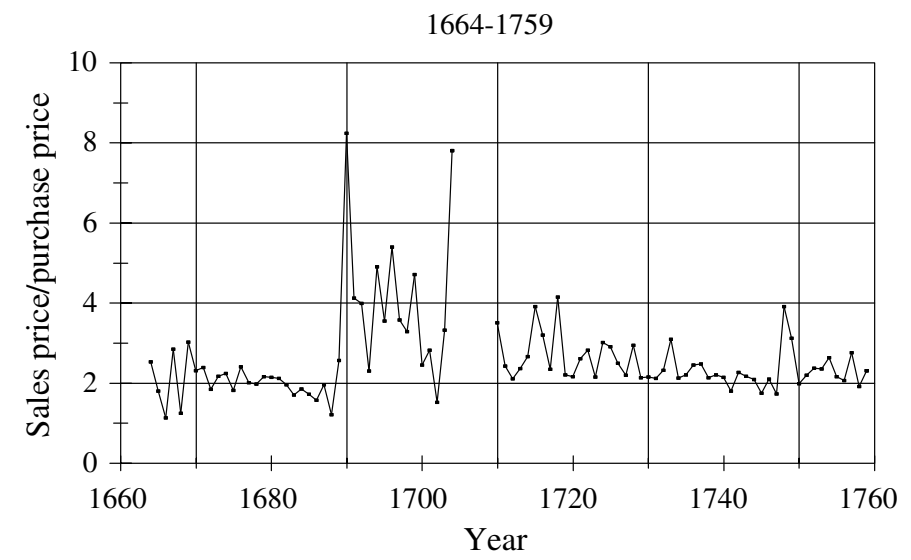

Figure 2. Asian textile trade markups. Source: O'Rourke and Williamson (2002b). 


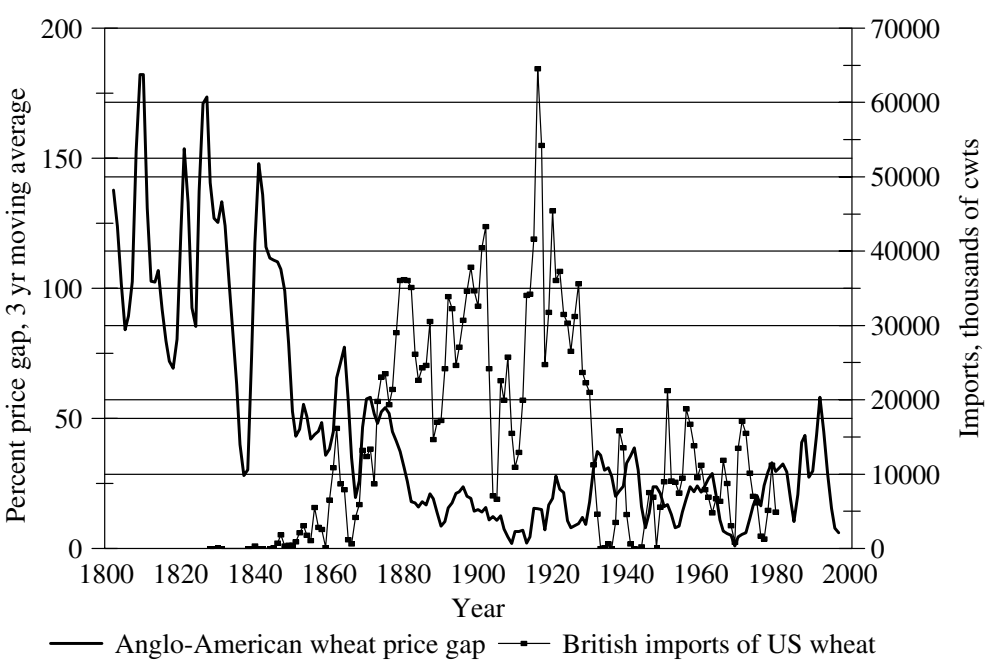

Figure 3. Anglo-America wheat trade. Source: for price gaps, see footnote 1; for British wheat imports: Mitchell (1988).

The key trade driving down European rents in the late 19th century was the trade in grain; unfortunately, we do not have intercontinental price gaps for grains prior to 1800. However, Figure 3 plots Anglo-American wheat price gaps from 1800 to $1999 .{ }^{1}$ The price gap fluctuated widely around an average of about 100 percent between 1800 and 1840, but did not systematically decline. After 1840 it fell sharply, reaching negligible levels by the eve of World War I. The timing of this decline in price differentials coincides with the timing of the switch in policy from mercantilism to trade liberalism when Britain removed navigation acts, removed import prohibitions and lowered average tariffs from about 71 percent in 1815 , to about 54 percent in the 1830 s, and to about 22 percent in the early 1840 s, before moving to virtual free trade in 1846 (Williamson, 1990). This British proglobal lead was then followed in the 1860s on the European continent (Bairoch, 1989). The timing of world commodity price convergence also coincides with the sustained decline in ocean freight rates documented by Harley (1988), and supports his view that the new transport technologies of the 19th century were crucial in revolutionizing world trade, rather than the institutional factors stressed by North (1958), which had been in operation from an earlier date. ${ }^{2}$ Finally, it

1 The British data are Gazette averages through 1980, and are taken from Mitchell (1988). After 1980, they are taken from the commodity price trends tables in the UK Annual Abstract of Statistics. The US data for 1870-1913 are taken from O'Rourke (1997), where they are expressed in shillings per cwt; these data are spliced on to the series in U.S. Department of Commerce (1975) for 1800-1870 and the US Department of Agriculture series for 1914-1999 (http://usda.mannlib.cornell.edu/usda/usda.html).

2 Thus, the Industrial Revolution did not just have a direct impact on factor prices through its effects on domestic technology; it also indirectly affected factor prices by promoting intercontinental trade. Trade, in turn, influenced the Industrial Revolution, and we discuss these linkages in Section 6. 
coincides with the emergence of large-scale wheat exports from the United States, as Figure 3 clearly shows.

The evidence of Figure 3 could be replicated many times over: by the late 19th century it is difficult to find commodities and pairs of markets for which there is no evidence of powerful commodity market integration. ${ }^{3}$ To take just three examples, London-Cincinnati percentage price differentials for bacon fell from 92.5 percent in 1870 to 17.9 percent in 1913; Liverpool-Bombay price differentials for cotton fell from 57 percent in 1873 to 20 percent in 1913; and LondonRangoon price differentials for rice fell from 93 to 26 percent over the same period (O'Rourke and Williamson, 1999, pp. 43-53). Commodity market integration during the century before World War I was a genuinely worldwide phenomenon, and it was immense.

\section{What Determined English Commodity and Factor Prices Prior to 1750 ?}

If sustained global commodity market integration only began in the 19th century then it follows that the distributional implications of international trade should only have begun to manifest themselves some time between Waterloo and the Great War. In order to test this hypothesis we gathered data on English factor endowments, commodity prices, productivity and factor prices from 1500 to 1936 . For these four centuries, we were able to construct: the ratio of agricultural land to the economy-wide labor supply (LANDLAB); the ratio of agricultural prices to industrial prices (PAPM); the ratio of wage rates to farm land rents (WR); total factor productivity in agriculture (TFPAG); and labor productivity in manufacturing (INDPROD). The sources of these English data are described in Appendix 1.

Figure 4 plots these five variables (expressed as natural logarithms) between 1500 and 1840, while Figure 5 shows their evolution between 1840 and 1936. The main argument of this paper emerges clearly from these figures. In both periods the land-labor ratio was trending down sharply. In a closed economy, this should have implied a falling wage-rental ratio. In principle, it should also have pushed up food demand relative to food supply, and raised the relative price of food. Figure 4 shows that both of these predictions held good for the earlier period. However, after 1840 the wage-rental ratio started to rise, despite an acceleration in the decline of land-labor ratios; while the relative price of food stopped rising, and eventually started to fall. Our argument is that after 1840 commodity prices began to be exogenous to the British economy; and wage-rental ratios were no longer primarily driven by land-labor ratios, but

3 Continental European grain markets protected by defensive tariffs provide one exception in the late 19th century: see O'Rourke (1997). Defensive protection against an invasion of European manufactures was even greater in Latin and North America, but it did not overturn the forces of global integration caused by transport improvements (Blattman et al., 2002; Coatsworth and Williamson, 2004; Williamson, 2002, 2005). 

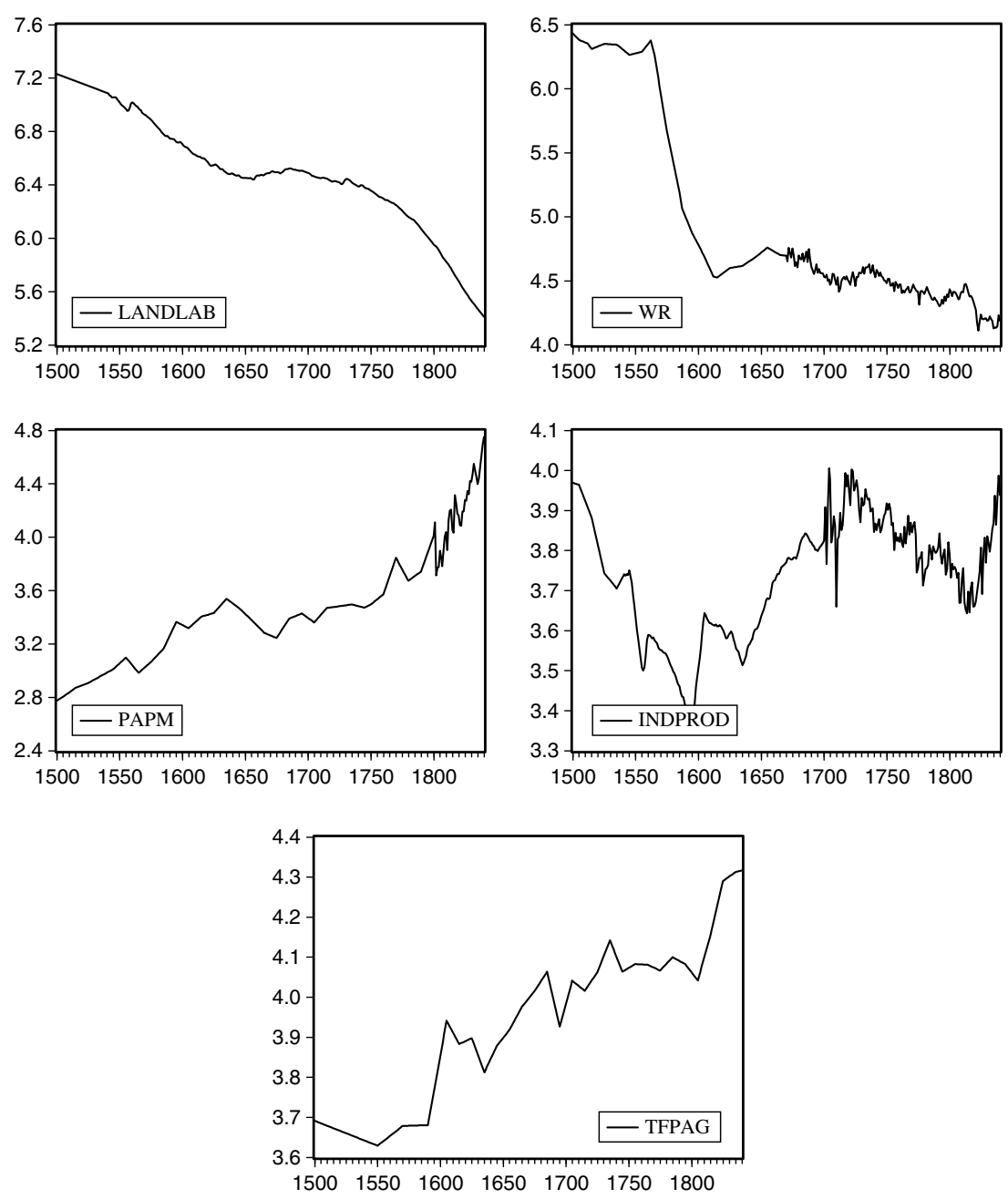

Figure 4. Raw data, 1500-1840. Source: Appendix 1.

rather by trade (i.e., an exogenously determined relative price of food) and by the Industrial Revolution (i.e., rising industrial productivity). But these are just assertions. Can econometric analysis bring further evidence to bear on these issues?

First, is it the case that English commodity prices were more closely linked to English endowments prior to the 19th century? And if so, when did this traditional (closed economy) relationship break down? Figure 6 explores the question of when the structural break took place: it assumes a simple log-linear relationship between relative commodity prices, PAPM, and the land-labor ratio LANDLAB, and plots Chow test statistics for every year between 1502 and 1935 to see where a structural 

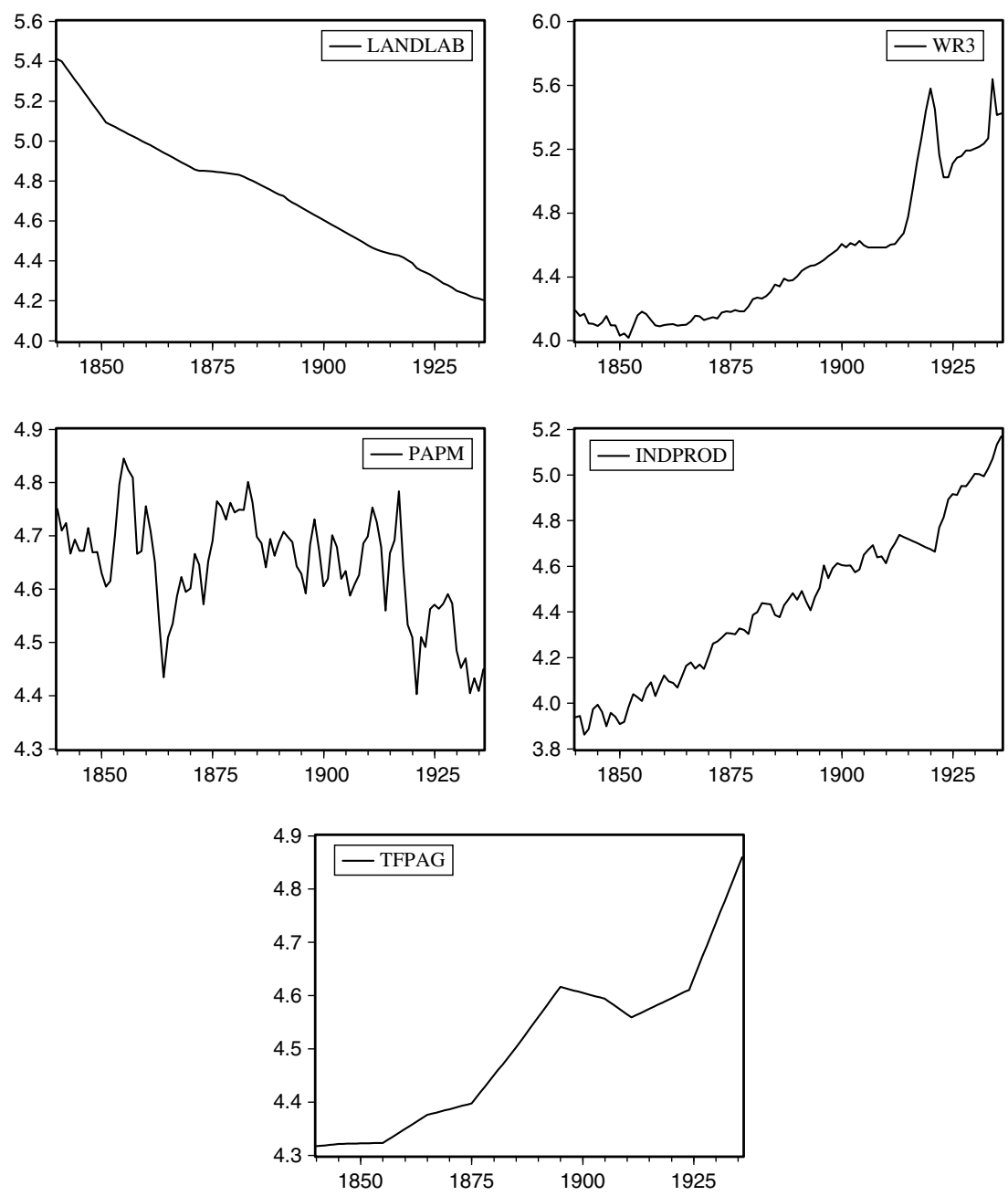

Figure 5. Raw data, 1840-1936. Source: Appendix 1.

break in this relationship is most likely to have taken place. There is a slow, hardly noticeable rise in the test statistic between 1500 and 1700 , followed by a significant rise from 1700 to 1750 , and a larger rise from 1750 to 1800 . This timing coincides well with what we know about the gradual opening of the English economy to international trade during the course of the 18th century: for example, the share of exports in national income rose from 8.4 percent in 1700 to 14.6 percent in 1760 and 15.7 percent in 1801 (Crafts, 1985, Table 6.6, p. 131). The figure suggests that traditional links between relative commodity prices and endowments were already breaking down during the 18th century, and we will have more to say about this in Section 6; however, the sharpest acceleration in the test statistic occurs between 


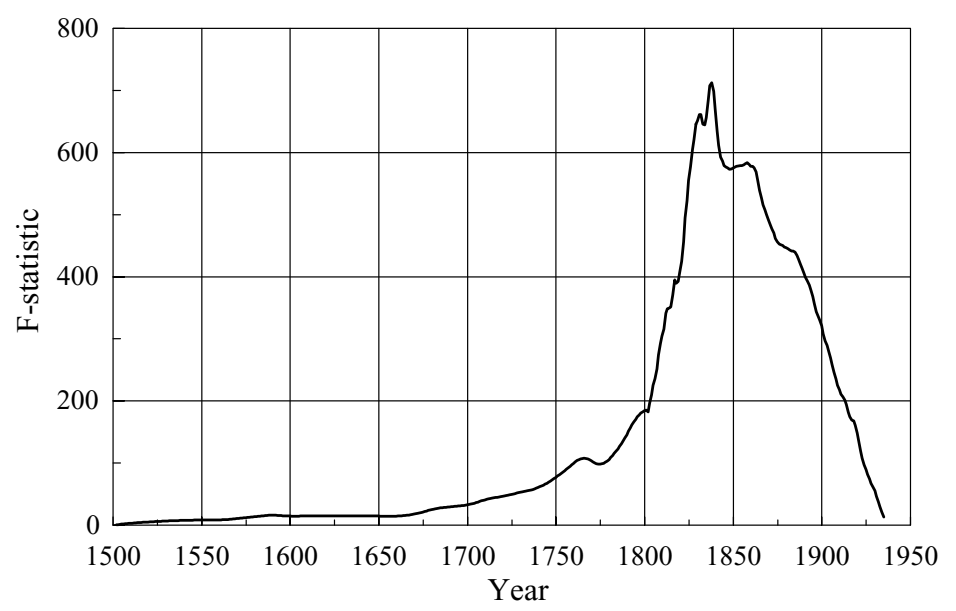

Figure 6. Chow test statistics. Source: see text.

about 1800 and 1840. Figure 6 suggests that the best candidate for a structural break is the second quarter of the 19th century, with the peak in the series occurring in 1838. Strikingly, this 1838 peak in Figure 6 is very similar to the timing of decline in both the Harley freight index and the UK-US grain price gap. Furthermore, it is consistent with qualitative accounts regarding the liberalization of trade policy which have long been a staple in the economic history literature. That is, the two decades or so after 1815 were full of pro-globalization policy changes. Prior to 1828 , grain imports were prohibited if domestic prices fell below a certain 'port-closing' level, and during the early postwar years grain imports were effectively excluded much of the time. In 1828, the Duke of Wellington's government replaced these import restrictions with tariffs which varied with the domestic price, a policy that not only lowered British grain prices but also increased the integration of British and Continental grain markets. Moreover, this adoption of the sliding scale tariff came at the end of a decade which had seen several other moves towards freer trade: a reform of the Navigation Acts in 1822; tariff reductions across the board; and the repeal of more than 1100 tariff acts in 1825 , the year in which the emigration of skilled workers was once again authorized. Of course, prior to 1815 the French Wars had severely restricted international trade (Findlay and O'Rourke, 2002). In short, by 1838 there had already been a radical liberalization of British commercial policy (Williamson, 1990), and Britain stuck with that pro-globalization policy stance up to the more famous 1846 Repeal of the Corn Laws and beyond. ${ }^{4}$

4 In a related paper, O'Rourke and Sollis (ongoing) search for the structural break using a variety of more sophisticated methods, including recursive OLS, Markov switching and multiple break models. They also conclude that there was a break in the relationship linking English relative commodity prices, and English endowments, some time in the early 19th century. 
Table 1 estimates a simple log-linear regression of PAPM on LANDLAB for the initial, closed economy period, which we take to be 1500-1750. As expected, the coefficient is negative; moreover, the regression passes standard Engle-Granger cointegration tests at the 10 percent level. ${ }^{5}$ We are only interested in the long run relationship between these two variables, and not in the short-run dynamics linking them; the OLS result gives us a super-consistent estimate of this coefficient, given that the relationship is cointegrating. ${ }^{6}$ Figure 7 plots the natural logarithm of PAPM, and of its predicted value generated by this regression (labeled PAPMF). Thus, PAPMF represents the relative price of agricultural goods that would have prevailed had they continued to be determined by domestic endowments after 1750. Since land-labor ratios continued to decline in Britain after 1750 , the regression predicts that the relative price of food should have

Table 1. Explaining relative commodity prices, $1500-1750$.

\begin{tabular}{lclr}
\hline \multirow{2}{*}{\multicolumn{1}{c}{ Variable }} & \multicolumn{2}{c}{ Dependent Variable: PAPM } \\
\cline { 2 - 3 } & \multicolumn{1}{c}{ Coefficient } & \multicolumn{1}{c}{ Standard error } & \\
\hline C & 8.372 & 0.168 & \\
LANDLAB & -0.764 & 0.024 & 0.996 \\
R-squared & 0.919 & Sum of squared residuals & 337.837 \\
Adjusted R-squared & 0.919 & Log likelihood & 0.017 \\
S.E. of regression & 0.063 & Durbin-Watson stat & $\mathrm{P}(\infty)=0.0860$ \\
ADF (3 lags) & -3.112 & $\mathrm{P}(247)=0.0897 ;$ & \\
\hline
\end{tabular}

Source: See text. Standard errors are Newey-West corrected.

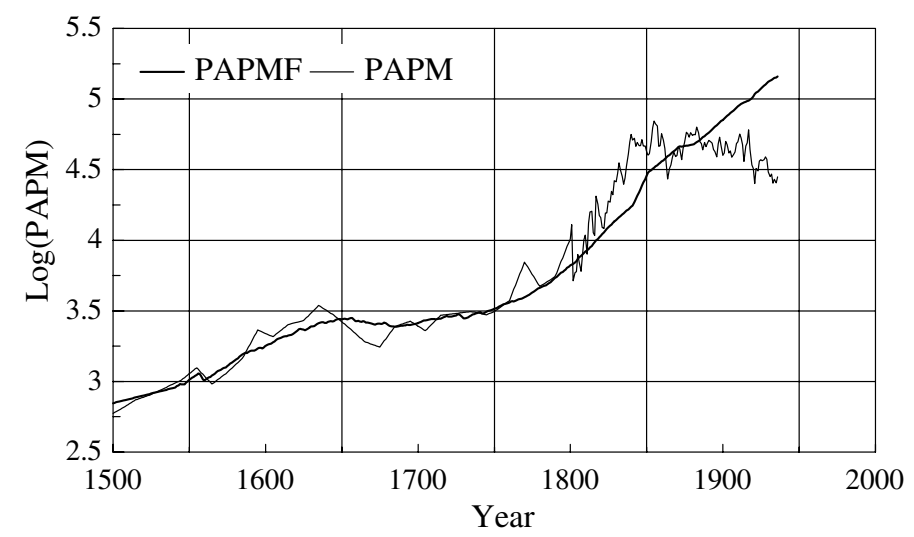

Figure 7. Actual and predicted PAPM. Source: see text.

5 Throughout, we calculate P-values for these cointegration tests using the program described in MacKinnon (1996).

6 We also tried Johansen cointegration techniques, and these results are reported in a later footnote. 
continued to rise, at an accelerating rate. But in fact it stopped rising somewhere around the middle of the 19th century, and then started to decline. Table 1 does a very good job of predicting the behavior of PAPM prior to the middle of the 18th century, but Figure 7 shows that it does a very poor job after the early or middle of the 19th century - consistent with the hypothesis that commodity prices became uncoupled and delinked from domestic endowments by the mid-19th century, and were determined on world markets thereafter.

How were wage-rent ratios determined in pre-19th century England? In a closed economy without trade, a decline in land-labor ratios should lead to a fall in the wage-rent ratio, and for standard Malthusian reasons. Rising industrial productivity, due either to rising capital-labor ratios or to better industrial technology, should raise wage-rent ratios, for reasons stated earlier. The impact of better agricultural technology on wage-rent ratios should depend on whether it was labor-saving or land-saving. Table 2 gives the results of regressing the wage-rent ratio (WR) on endowments (LANDLAB), on industrial productivity (INDPROD), and on agricultural productivity (TFPAG), for the years 1500-1750. (Once again, all variables are expressed in natural logarithms.) As expected, the wage-rent ratio was positively related to the land-labor ratio. As expected, it was also positively related to industrial productivity. The wage-rent ratio was negatively related to agricultural productivity, suggesting that technical change in early modern English agriculture tended to be labor-saving or land-using, which is what socialist critics of the enclosure movement have long maintained (Marx, 1867; Dobb, 1946), a position that has found impressive support in recent empirical analysis (Allen, 1992: Chap. 11). ${ }^{7}$

7 The relationship is at the margins of cointegration, passing the Engle-Granger test at the 14 percent level. We also used Johansen methods to search for cointegrating relationships between all five variables (further details available on request). Both the trace and max-eigenvalue tests indicated that there were 3 such relationships (at the 5 percent confidence interval). The data easily allowed us to place a number of coefficient restrictions on the model (the P-value of the relevant LR test being 0.67 ), and the results were as follows (standard errors in parentheses):

WR - 2.01 LANDLAB $=0$; $(0.20)$

PAPM +0.75 LANDLAB $=0$ $(0.03)$

INDPROD - 0.70 LANDLAB -1.88 TFPAG $=0$

The elasticity of PAPM with respect to LANDLAB is almost identical to that estimated by OLS methods; while the elasticity of WR with respect to LANDLAB is somewhat bigger (2.01 as opposed to 1.66). The interpretation of the third equation is straightforward: industrial productivity depends not only on TFP in industry, but on capital-labor ratios there as well; it is therefore sensitive to the intersectoral allocation of labor. Rising land-labor ratios or better agricultural technology might well imply a higher demand for labor in agriculture, thus raising capital-labor ratios in industry. It should be clear that the argument in the text would be qualitatively unaffected if we used these estimates; in the absence of structural change, PAPM would have continued to rise at the same rate as in Figure 7, and WR would have continued to fall (even more rapidly than in Figure 8, since the Johansen elasticity of WR with respect to LANDLAB is higher), as the land-labor ratio kept falling. 
Table 2. Explaining Wage-Rent Ratios, 1500-1750.

\begin{tabular}{lrlr}
\hline \multirow{2}{*}{\multicolumn{1}{c}{ Variable }} & \multicolumn{2}{c}{ Dependent Variable: WR } \\
\cline { 2 - 3 } C & Coefficient. & \multicolumn{1}{c}{ Standard Error } \\
LANDLAB & -2.190 & 3.355 \\
TFPAG & 1.664 & 0.298 & \\
INDPROD & -1.966 & 0.586 & 8.579 \\
R-squared & 1.021 & 0.298 & 67.553 \\
Adjusted R-squared & 0.941 & Sum of squared residuals & 0.053 \\
S.E. of regression & 0.940 & Log likelihood & $\mathrm{P}(\infty)=0.1298$ \\
ADF (14 lags) & 0.186 & Durbin-Watson stat & \\
\hline
\end{tabular}

Source: See text. Standard errors are Newey-West corrected.

Table 3 uses these results to decompose changes in the wage-rent ratio into those components which were due to changes in LANDLAB, TFPAG and INDPROD. Panel A reports the actual changes in these variables between 1500 and 1750. Panel $\mathrm{B}$ then uses the coefficients from Table 2 to derive the change in the wage-rent ratio due to changes in each of these three exogenous variables and an unexplained residual. These impact estimates are all expressed as percentages of the actual change in WR. Thus, the first row of panel B shows that 53.2 percent of the 16th century decline in wage-rent ratios was due to falling landlabor ratios; 19.5 percent was due to improved agricultural labor-saving technology; and 28.5 percent was due to a decline in industrial productivity; leaving very little unexplained by the residual. Over the period as a whole, the dominant factors pushing down the wage-rent ratio were a rising population and laborsaving improvements in agricultural technology: according to the final row of panel B, 74.5 percent of the decline in wage-rent ratios in the 250 years after Columbus was due to falling land-labor ratios, while 38.5 percent was due to labor-saving improvements in agricultural technology. Falling industrial productivity between 1500 and 1600 reinforced those trends, but rising industrial productivity from 1600 onwards served to counter them. Over the 250 years as a whole, changing industrial productivity had little impact on changing wage-rent ratios. Residual forces, unaccounted for by the regression in Table 2, served to lower the wage-rent ratio, but those forces were not very powerful over the quarter millennium as a whole. However, note that those residual forces rose over time. Indeed, the very large residual which appears at the end of the period, between 1700 and 1750, signals that these closed-economy, pre-industrial relationships were already breaking down in the first half of the 18th century. Still, the main message emerging from Table 3 is that population pressure on the land was crucial in explaining the collapse in the wage-rent ratio before 1750, an empirical finding fully consistent with a 'Malthusian' characterization of the pre-industrial epoch. 
Table 3. Decomposing changes in wage-rent ratios, 1500-1936.

\begin{tabular}{|c|c|c|c|c|c|}
\hline & \multicolumn{5}{|c|}{ Panel A. Actual movements in variables 1500-1750 (change in log) } \\
\hline & WR & LANDLAB & TFPAG & INDPROD & \\
\hline \multirow{4}{*}{\multicolumn{2}{|c|}{$\begin{array}{l}1500-1600-1.7 \\
1600-1700-0.2 \\
1700-1750-0.1 \\
1500-1750-1.9\end{array}$}} & -0.5 & 0.2 & -0.5 & \\
\hline & & -0.2 & 0.1 & 0.3 & \\
\hline & & -0.1 & 0.1 & 0.1 & \\
\hline & & -0.9 & 0.4 & -0.1 & \\
\hline & \multicolumn{5}{|c|}{ Panel B. Explaining movements in WR 1500-1750 (percent accounted for) } \\
\hline & TOTAL & LANDLAB & TFPAG & INDPROD & RESIDUAL \\
\hline $1500-16001$ & 100.0 & 53.2 & 19.5 & 28.5 & -1.1 \\
\hline $1600-17001$ & 100.0 & 143.9 & 103.5 & -131.6 & -15.8 \\
\hline $1700-17501$ & 100.0 & 421.4 & 335.2 & -183.0 & -473.7 \\
\hline \multicolumn{2}{|c|}{$1500-1750100.0$} & 74.5 & 38.5 & 2.7 & -15.7 \\
\hline & \multicolumn{5}{|c|}{$\begin{array}{l}\text { Panel } C . \text { Counterfactual change in WR and actual movements in other variables } 1750-1936 \\
\text { (change in log) }\end{array}$} \\
\hline & WRCF & LANDLAB & TFPAG & INDPROD & \\
\hline \multirow{3}{*}{$1750-1936$} & -3.9 & -2.2 & 0.8 & 1.3 & \\
\hline & \multicolumn{5}{|c|}{ Panel D. Explaining movements in counterfactual WR 1750-1936 (percent accounted for) } \\
\hline & WRCF & LANDLAB & TFPAG & INDPROD & RESIDUAL \\
\hline \multirow{3}{*}{ 1750-1936 } & 100.0 & 93.0 & 40.1 & -33.1 & 0.0 \\
\hline & \multicolumn{5}{|c|}{ Panel E. Actual movements in variables 1842-1936 (change in log) } \\
\hline & WR & INDPROD & PAPM & & \\
\hline \multirow{3}{*}{$1840-1936$} & 1.3 & 1.3 & -0.3 & & \\
\hline & \multicolumn{5}{|c|}{ Panel F. Explaining movements in WR 1842-1936 (percent accounted for) } \\
\hline & TOTAL & INDPROD & PAPM & RESIDUAL & \\
\hline $1840-19361$ & 100.0 & 108.4 & 19.0 & -27.4 & \\
\hline
\end{tabular}

Source: See text.

\section{What Determined Factor Prices After 1840?}

Figure 8 displays the central fact motivating this paper. The predicted WR in the figure is the natural logarithm of the wage-rent ratio which the pre-1750 relationship estimated in Table 2 implies for the full 450 years after Columbus: that is to say, it takes the regression coefficients estimated in Table 2, and applies these to the actual movements in LANDLAB, TFPAG and INDPROD over the entire period. From 1750 on it thus represents a counterfactual WR series which would have obtained had there been no fundamental regime change. If pre-industrial relationships had been sustained, the wage-rent ratio would have continuously declined throughout, and at a much more rapid rate in the 19th century than before. Panel C of Table 3 


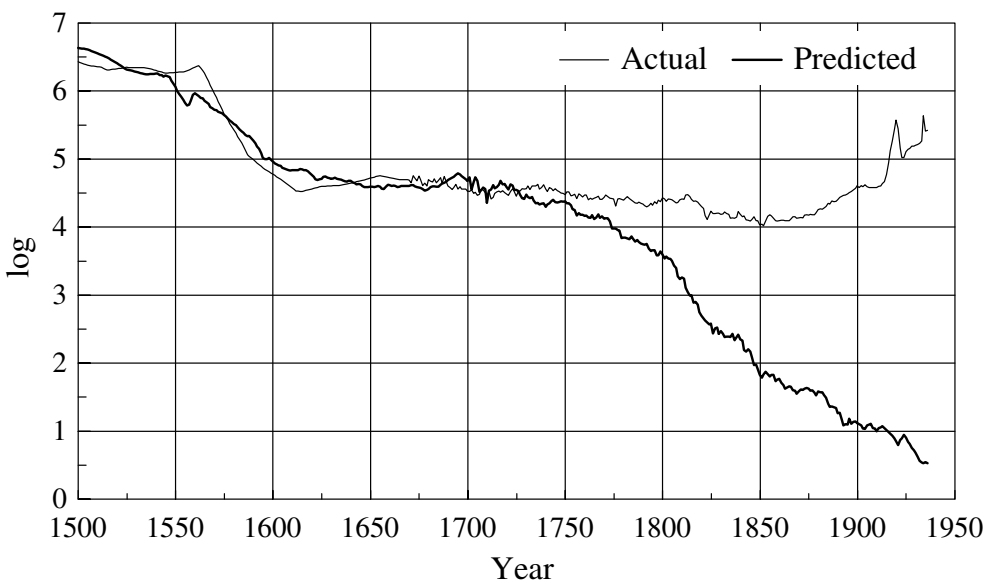

Figure 8. Actual \& predicted w/r. Source: see text.

reports the change in this counterfactual wage-rent ratio series (WRCF) between 1750 and 1936, as well as the actual changes in the exogenous variables which are driving the counterfactual series. Panel D then decomposes the change in the counterfactual series into the components explained by changes in each of the three exogenous variables. Declining land-labor ratios explain almost the entire decline in the counterfactual series (93 percent); more rapid (labor-saving) technological progress in agriculture also helps push down counterfactual wage-rent ratios (40 percent), but this agricultural productivity effect is almost entirely offset by the impact of even more rapid improvements in industrial productivity ( -33 percent).

If there had been no fundamental change in regime, 19th century wage-rent ratios would have continued to decline rapidly, but this is not at all what happened. On the contrary, Figure 8 shows that the wage-rent ratio actually declined at a far more sedate pace until 1850 or so, before turning around and increasing markedly. What explains this dramatic departure from the historical norm? Was it the industrial revolution, which pulled workers into the cities at an accelerating pace, thus raising wage-rent ratios? Or was it the growing internationalization of the British economy, effectively raising Britain's land-labor ratio by importing land-intensive foodstuffs and manufacturing intermediates (e.g., cotton, wool and timber) produced on more abundant land overseas? Or was it both?

Table 4 estimates a (log-linear) open-economy model of the wage-rent ratio over the period $1842-1936 .{ }^{8}$ This period was chosen since the previous two sections suggested that it was only after the late 1830 s that the transition was complete

8 O'Rourke and Williamson (2002c) show that while closed economy models similar to the one estimated earlier work well before 1800, they do not work at all well from the 19th century on. Similarly, open economy models work well for the later period, but not for the earlier one. 
Table 4. Explaining wage-rent ratios, 1842-1936.

\begin{tabular}{lllr}
\hline & \multicolumn{2}{l}{ Dependent Variable: WR } \\
\cline { 2 - 3 } \multicolumn{1}{c}{ Variable } & Coefficient & \multicolumn{2}{c}{ Standard Error } \\
\hline C & 3.920 & 2.140 & \\
INDPROD & 1.041 & 0.096 & \\
PAPM & -0.868 & 0.406 & 3.145 \\
R-squared & 0.828 & Sum of squared residuals & 27.087 \\
Adjusted R-squared & 0.825 & Log likelihood & 0.299 \\
S.E. of regression & 0.185 & Durbin-Watson stat & $\mathrm{P}(\infty)=0.0777$ \\
ADF (1 lag) & -3.562 & $\mathrm{P}(89)=0.0914 ;$ & \\
\hline
\end{tabular}

from a relatively closed economy to a relatively open one in which relative commodity prices were effectively delinked from domestic endowments; 1842 was also the date of a major liberalization of the grain trade. In an open economy, WR could still be a function of INDPROD, TFPAG and LANDLAB (assuming that the number of factors exceeds the number of traded goods), but it should also be a function of relative commodity prices PAPM, which are now taken as exogenous in a newly globalized world. The specific factors trade model predicts that as the relative price of food declines, resources should be transferred out of agriculture, and land rents (returns to the immobile factor) should fall relative to wages (returns to the mobile factor): thus WR should be a negative function of PAPM. TFPAG and LANDLAB are omitted from the regression since when equations were estimated including them, the coefficients on TFPAG and LANDLAB were statistically insignificant, and the equations failed Engle-Granger cointegration tests. We are thus left with a parsimonious specification in which the wagerent ratio is a function of industrial productivity and relative commodity prices alone. As Table 4 shows, WR was again positively related to industrial productivity, and the estimated coefficient is almost exactly the same as that found in Table 2 for 1500-1750 (i.e., 1.04, as opposed to 1.02). Furthermore, WR was negatively related to the relative price of agricultural goods, just as trade theory suggests. The equation passes the Engle-Granger cointegration test at the 10 percent level. Again, we stress that we are only interested in the long-run relationships linking these variables, and OLS methods should provide us with good estimates of these relationships given cointegration. ${ }^{9}$

9 Again, we tried using Johansen methods to find cointegrating relationships between WR, INDPROD and PAPM; the trace statistic indicated 1 relationship at the 5 percent confidence level. Normalizing the coefficient on WR to unity, the estimate is as follows (standard errors in parentheses):

WR +3.63 PAPM - 0.70 INDPROD $=0$

$(0.79) \quad(0.21)$ 
Panel E of Table 3 reports the actual changes in WR, INDPROD and PAPM between 1842 and 1936, while Panel F decomposes the change in WR into those portions due to changing industrial productivity and changing relative prices. From the results in Panel $\mathrm{F}$ it might appear that the industrial revolution was the dominant actor in the story, while globalization was only a bit player. After all, the rise in industrial productivity accounted for all of the rise in the wage-rent ratio after 1842, while falling relative agricultural prices accounted for "only" a fifth of the rise (and the impact of PAPM was almost precisely offset by residual factors). However, this decomposition is a grossly inaccurate reflection of the impact on factor prices of Britain opening up to intercontinental trade between the 1820s and 1840s, since the decomposition measures the impact of changing commodity prices relative to an implicit counterfactual of no change in relative commodity prices. In fact, the appropriate no-trade counterfactual is one of a continued rise in relative agricultural prices (Figure 7), and it is against that counterfactual that the impact of the regime switch to openness should be gauged.

Figure 9 supplies a far more accurate accounting of the relative impact of trade and the industrial revolution in explaining the turn-about in wage-rent trends after the 1830s. It reports the actual behavior of the wage-rent ratio from 1842 onwards (based on fitted values from the regression in Table 4) and the "predicted" wage-rent ratio which would have applied had pre-1750 relationships persisted (based on fitted values from the regression in Table 2). While the wagerent ratio in fact increased almost five-fold over the period, it would have declined by more than 80 percent had it continued to evolve according to pre-1750

\section{Footnote 9 Continued}

The results are qualitatively, if not quantitatively, similar to those presented in Table 4. Using the Johansen estimates would imply a much bigger elasticity of the wage-rental ratio with respect to prices, and a smaller elasticity of the wage-rental ratio with respect to industrial productivity, than those implied by Table 4 . This would strengthen our argument (since we would then find that rising industrial productivity had a smaller effect on the wage-rental ratio, and that commodity prices had an even bigger effect).

Another partial test of the plausibility of these results comes from asking what simple trade theory would predict about the size of the coefficients. Assume a two-sector specific factors model, with food (A) produced by land and labor, and manufactured goods (M) produced by labor and capital. We have: $a_{R A} d+a_{L A} W=p_{A}$ and $a_{K M} r+a_{L M} W=p_{M}$ where the $a_{i j}$ 's are unit input requirements of $\mathrm{R}$ (land), L (labor) and $\mathrm{K}$ (capital) into the two sectors, $\mathrm{A}$ and $\mathrm{M}$; $\mathrm{d}$, w and $\mathrm{r}$ are the returns to land, labor and capital respectively; and $\mathrm{p}_{\mathrm{i}}$ is the price of good $\mathrm{i}$. Totally differentiating both equations, and making use of Jones (1971, p. 7, equation 1.11), it is easy to derive an algebraic expression relating the percentage change in $(\mathrm{w} / \mathrm{d})$ to percentage changes in $\left(\mathrm{p}_{\mathrm{A}} / \mathrm{p}_{\mathrm{M}}\right),(\mathrm{R} / \mathrm{L})$ and $(\mathrm{K} /$ L). As usual, the implied coefficients depend on cost shares in the two sectors, $\theta_{\mathrm{ij}}$, and on intersectoral labor allocation shares $\lambda_{\mathrm{Li}}$. Assuming $\lambda_{\mathrm{LA}}=0.25, \quad \lambda_{\mathrm{LM}}=0.75, \quad \theta_{\mathrm{KM}}=0.4$, $\theta_{\mathrm{RA}}=0.5$, and elasticities of substitution in agriculture (1.0) and industry (0.5), yields a predicted coefficient on relative prices of -1.3 , not so different from our OLS estimate $(-0.87)$; and a predicted coefficient of 1.04 on INDPROD (taken to be driven by $\mathrm{K} / \mathrm{L}$ ), which is identical to the estimate we obtained in Table 4. In the Johansen framework, we are able to impose the restriction that the coefficient on INDPROD is 1.04 (the relevant P-value is 0.17 ); in this case the elasticity of WR with respect to PAPM becomes -2.71 . 


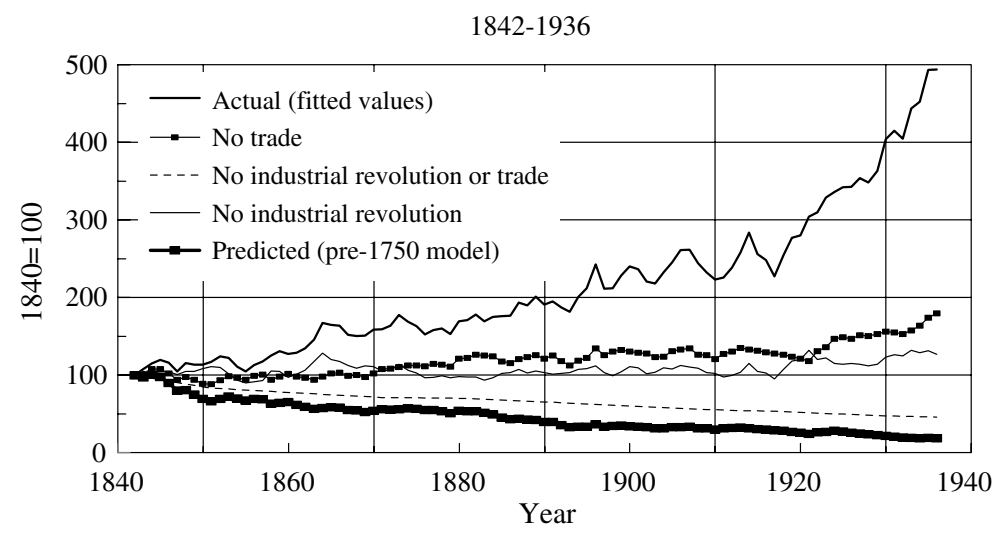

Figure 9. Actual \& counterfactual w/r. Source: see table.

relationships. The figure also plots three counterfactual wage-rent ratio series. The first, labeled 'no industrial revolution,' is again based on the estimated equation in Table 4, but holds the level of industrial productivity constant in every year (at its 1842 level). Thus, it shows the wage-rent ratios which would have obtained had relative commodity prices evolved in the way they did, but had there been no improvement in industrial productivity from 1842 onwards. As can be seen, if there had been no increase in industrial productivity over that century, the wagerent ratio would have remained roughly constant throughout-rising up to 1936 by a mere 27 percent, rather than recording an actual increase of 394 percent. Presumably, this is the channel of causation-from the industrial revolution to rising wage-rent ratios - which would have been favored by Jones, Galor and Weil, Lucas and other theorists, had they addressed this relative factor price issue explicitly. ${ }^{10}$

The second series, labeled 'no trade,' also uses the coefficients which were estimated in Table 4. It assumes that the English economy remained relatively closed to international trade, and, to be more precise, that relative commodity prices continued to be determined by domestic factor endowments after the 1830s. This counterfactual thus allows INDPROD to evolve as it did, but substitutes the counterfactual PAPMF series in Figure 7 for the actual PAPM series. As can be seen from Figure 9, if there had been no open economy forces causing relative commodity prices to diverge from their historical trajectory the wage-rent ratio would have remained relatively constant between 1842 and 1936, increasing by a mere 80 percent, rather than by 394 percent as actually occurred. Figure 9 suggests that globalization and the industrial revolution had roughly equal effects on wage-rent ratios throughout this period: the two counterfactual series are

10 In fact, several papers in this literature (e.g. Galor and Weil, 2000; Jones, 2001; Galor and Mountford, 2002) assume that returns to land are zero for reasons of analytical tractability. 
remarkably close to each other. Finally, the 'no industrial revolution and no trade' series holds INDPROD constant as before, and also substitutes PAPMF for PAPM as in the 'no trade' counterfactual. In this final counterfactual, the wagerent ratio actually falls by 54 percent between 1840 and 1936, and at almost the same rate as if pre-1750 relationships had been maintained.

These counterfactuals invite two conclusions. First, industrial revolutionary forces and the opening up of the English economy to trade together explain the historic reversal in long-run wage-rent ratio trends from Columbus to World War II. If industrial productivity had failed to increase, and if relative commodity prices had continued to evolve as they had done prior to 1750 , then the wage-rent ratio would have continued to decline after the 1830 s as it had since 1500 , and by a substantial amount. However, once INDPROD and PAPM are allowed to evolve as they actually did, our econometric model replicates the actual rise in wage-rent ratios which took place after 1840 . Second, and just as important, while the long-run turnaround in wage-rent ratio trends can be explained partly by industrial revolutionary forces, it is also explained by the open economy forces identified long ago by Eli Heckscher and Bertil Ohlin. Comparing the 'no trade' and 'no industrial revolution' series in Figure 9, it would appear that trade was just as important as industrial revolutionary forces in explaining the historic relative factor price turn-around. A closed economy account of the revolutionary change in growth and distribution performance during the 19th century misses half the story.

\section{The Transition, $1750-1840$}

We have argued that Britain underwent two important regime switches during the late 18th and early 19th centuries, not just one. The first was a transition to modern industrial growth and the second was a transition towards a more open trading environment. These regime switches were not abrupt, but rather took place over a number of decades. Also, the two transitions were almost certainly connected. This section will elaborate on these two issues.

Traditional economic history has always taught that the Industrial Revolution marked a sharp and "revolutionary" discontinuity. The older evidence seemed to support this view; for example, Hoffmann's (1955) data show a dramatic acceleration of industrial output after 1770. More recent work, however, has found that aggregate growth and technical change were much slower between 1770 and 1830 than had been previously thought (e.g., Crafts and Harley, 1992), with technical change largely concentrated in a number of key industries. Moreover, the aggregate growth rate had been steadily increasing since the beginning of the 18 th century. Thus, "the origins of modern economic growth extended over a longer time period and a wider geographical area than are traditionally encompassed in studies of the Industrial Revolution" (Harley and Crafts, 2000, pp. 820-821). Furthermore, there is another tradition that focuses on pre-factory cottage industry development, so-called proto-industrialization. This recent 
scholarship has encouraged some to discard the phrase "industrial revolution" entirely!

While the price gap evidence outlined in Section 3 certainly documents a stark contrast - no intercontinental price convergence before 1800, but substantial price convergence thereafter - it is important to note that the move to a more open British economy had also been taking place over a long period. To repeat, the share of exports in British national output gradually rose from 8.4 percent in 1700 to 14.6 percent in 1760, 15.7 percent in 1801, and 19.6 percent in 1851 (Crafts, 1985, Table 6.6, p. 131). Furthermore, the role of intercontinental trade was also increasing throughout the 18th and early 19th centuries: Europe took 85.3 percent of English exports in 1700-1701, but only 77 percent in 1750-1751, 49.2 percent in 1772-1773, and 30.1 percent in 1797-1798. The Americas (the source of abundant land) were the most important overseas destination, with their share of total exports rising from 10.3 to 57.4 percent over the same period (O'Brien and Engerman, 1991, Table 4, p. 186). Figure 6 indicated that traditional "Malthusian" relationships between English prices and endowments were already breaking down during the 18th century, consistent with this gradual opening of the economy. True, wars continuously served to interrupt the contribution of long run fundamentals pushing international commodity market integration. For example, O'Rourke and Williamson (2002b) find a spike in the Euro-Asian clove price gap which coincided with the Seven Years War (1756-1763), and an increase in coffee and black pepper price gaps during the 1790s which coincided with the outbreak of the French and Napoleonic Wars. The Pax Britannica that prevailed after Waterloo allowed those fundamentals to exert their full impact. These included the technological breakthroughs in transport which were crucial in driving down freight rates so dramatically in the 19th century (Harley, 1988).

Finally, the two revolutions which we argue were responsible for reversing the long run decline in wage-rent ratios were connected in a number of ways - although the precise nature of these links remains a subject of lively debate. ${ }^{11}$ Most obviously, and as noted earlier, the innovations which drove down freight rates - notably the metal steamship - depended on the steam engine and developments in metallurgy which together constituted some of the most notable technological breakthroughs of the Industrial Revolution. But the causation may also have gone the other way around, from trade to the Industrial Revolution. While it is clear that the industrial revolution was supply-driven, and that export demand was therefore not the cause of it in any old-fashioned Keynesian sense (Mokyr, 1977), and while Marxist accounts of the industrial revolution, which link

11 For a recent survey of the historiography, see Morgan (2000). One theorist has actually constructed a computable model of the process and used it to decompose the sources of the British industrial revolution into trade and technology forces (Stokey, 2001). Testing such a model against competitors is, of course, a difficult task. In any case, economists have had an equally difficult (and contentious) time trying to disentangle the late 20th century impact of globalization on growth and inequality. 
British accumulation to profits derived from the colonial trade, do not withstand empirical scrutiny either (O'Brien, 1982), it is difficult to imagine that English industrial growth between 1750 and 1850 would have been as rapid as it was without ample and elastic supplies of imported raw materials such as cotton, and the ability to sell industrial output in overseas markets (Findlay, 1982, 1990; O'Brien and Engerman, 1991). Overseas markets were in fact far more important for industry than for the economy as a whole: the export share in gross industrial output was 24.4 percent in 1700 (the economy-wide share was 8.4 percent), and 34.4 percent in 1801 (the economy-wide share was 15.7 percent; O'Brien and Engerman, 1991, p. 188). Between 1780 and 1801, the increase in industrial exports was 46.2 percent of the increase in gross industrial output; in 1801, exports were 24 percent of iron output, and an astonishing 62 percent of cotton output. While no scholar has quantified what would have happened to British investment incentives had industrialists been forced to sell their output solely on domestic markets, and source all their raw materials domestically, the direction of the effect seems obvious. Without trade, the prices of manufactures would have declined by more than they actually did, and manufacturing inputs would have been far more expensive. Thus, profitability and (presumably) investment would have been lower. ${ }^{12}$ Furthermore, an elastic supply of raw cotton to the British economy required not only elastic supplies of New World land, but elastic supplies of slave labor as well. Thus, the British Industrial Revolution was intimately bound up with the Triangular Trade linking Africa, Europe and the Americas (Findlay, 1990).

\section{Conclusion}

This paper has provided evidence of a dramatic structural break in European long run relative factor price trends which coincided with the more familiar break which occurred in living standards and aggregate productivity behavior. If the wage-rent ratio had continued to follow the same laws of motion after 1750 as before it would have declined continuously throughout the 19th and early 20th centuries, and at an accelerating rate as population growth increased and the land-labor ratio fell ever more dramatically. Instead, the decline stopped and the trends reversed, with a modern rise starting sometime after 1850 .

We have argued that this reversal in wage-rent ratio trends was due not only to the industrial revolution, but to the opening of the English economy to trade. Evidence on falling transport costs, rising liberal policy, evaporating international commodity price gaps, rising trade shares, and the relationship between commodity prices and factor endowments all suggest that the English economy became much more open to trade during the 18th and early 19th centuries, and

12 In addition, textile fibers such as wool were less easily mechanized than raw cotton, making a counterfactual switch from imported cotton to domestic wool very difficult. 
particularly during the quarter century or so after Waterloo. By the middle of the 19th century relative commodity prices no longer evolved as if they were determined by English factor endowments; relative agricultural prices stopped their secular rise, and eventually even started to decline. We have shown that trade was just as important as rising industrial productivity in explaining the reversal in wage-rent ratio trends after 1840 . Factor price ratios would not have increased dramatically in the absence of industrial revolutionary forces; nor would they have increased dramatically had relative commodity prices continued to be determined by domestic factor endowments, as they had been for the centuries before 1750 .

While this is a paper about England, there is some suggestive American evidence which reinforces our conclusions. In a closed economy environment, the eastern American seaboard should have seen their wage-rental ratios fall as their populations grew and land-labor ratios fell; in an open economy environment, trade should have pushed up still farther the relative price of food and other resource-intensive products in which the region had a comparative advantage, and thus reinforced the impact of population growth, leading to even more rapid declines in the wage-rental ratio. Thus, in the closed economy period wage-rental ratios in Britain and the US should have moved in the same direction (downward), while in the open economy period they should have diverged. The data on pre-1800 US wage-rent ratios are sparse, but what we have is consistent with these speculations. Thus, as Figure 10 shows, in Connecticut free wage-rent ratios more than halved between the 1680s and the late 1750s, and fell again in the decades before the Revolution (Williamson and Lindert,1980, p. 21); while in South Carolina the trend in the ratio of slave prices to land values was broadly downwards during the last three quarters of the 18th

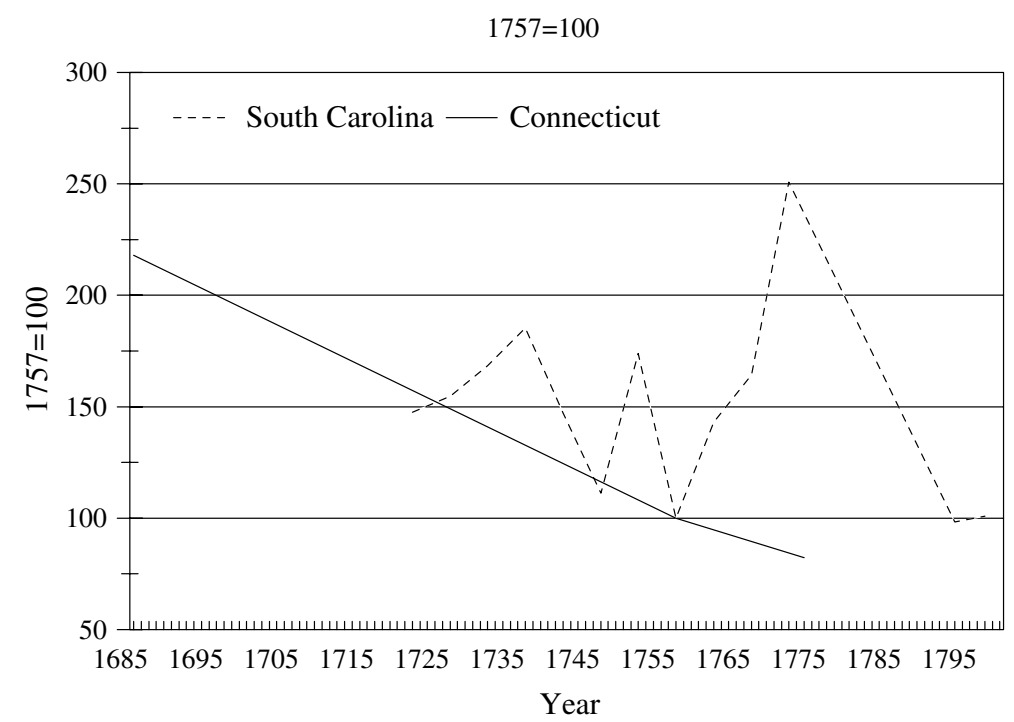

Figure 10. Wage-rental ratios $1685-1798$. Souce: see text. 
century (Mancall et al., 2001, 2002), at least if one ignores the spike in the years just before the Revolution. Unlike in England, this trend did not reverse after the emergence of large-scale intercontinental trade in basic commodities; rather, the US wage-rental ratio fell by almost 60 percent between 1870 and the Great War (O'Rourke et al., 1996; O'Rourke and Williamson, 1999).

While this paper offers strong evidence that trade produced distributional regime shifts during this period, we think its importance is understated. After all, we have ignored the possibility that the industrial revolution may itself have been intimately connected with the development of international trade during the 18th and early 19th centuries. Without the possibility of intercontinental trade, industrial productivity would almost certainly have increased by less than it actually did during the industrial revolution: trade may not have kick-started the First Industrial Revolution, but it surely played an indispensable supporting role. ${ }^{13}$ Open economy forces must have played an even more important role after 1750 than our already-impressive econometric results suggest.

\section{Acknowledgments}

We have been helped with the wage-rent data by Greg Clark as well as by the excellent research assistance of Darya Zhuck. In addition, the comments of Stephen Broadberry and Louis Cullen are gratefully acknowledged, as are those of participants at the Ohlin Conference (Stockholm, October 14-16, 1999), the Sound Conference (Copenhagen, March 1, 2002), ERWIT 2002 (Munich, June 14-17, 2002), the ISSC/HII Conference on "Past and Present: Long-term Perspectives on the World Today" (Dublin, October 18, 2002), the NBER ITI Winter Institute (Palo Alto, December 7, 2002), the Minerva Center Conference on "From Stagnation to Growth"(Rorschach, Switzerland, May 2-4, 2003); and seminar participants at ANU, Glasgow, Gotenborg, Harvard, Humboldt, Illinois, London School of Economics, Melbourne, New South Wales, Stockholm School of Economics, Western Australia, and the Economic and Social Research Institute, all of whom heard early and preliminary versions of this paper. O'Rourke is an IRCHSS Government of Ireland Senior Fellow and acknowledges the generous funding of the Irish Research Council for the Humanities and Social Sciences. Williamson acknowledges financial support from the National Science Foundation SES-0001362. The usual disclaimer applies.

13 Indeed, Acemoglu et al. (2002) have offered new evidence recently that participation in the Atlantic economy was essential in making modern Western European growth possible before 1850 . 
Appendix 1. English Wages, Land Rents, Inter-Sectoral Terms of Trade, Land-Labor Ratios and Sectoral Productivity 1500-1936

Nominal Agricultural Wages 1500-1936 $(1900=100)$

1500-1670: Male day wages in agriculture, pence per day; reported decadal, interpolated geometrically to get annual; from Clark, G. The Long March of History: Farm Laborers' Wages in England 1208-1850, Mimeo, Davis (n.d.): University of California, Table 4, p. 26.

1670-1851: "Winter" farm wages, pence per day; annual; from Clark, G. (August 2001). "Farm Wages and Living Standards in the Industrial Revolution: England, 1670-1850," Economic History Review 54(3), pp. 477-505.

1851-1902: Average weekly cash wages of ordinary laborers paid 67 farms in England and Wales, shillings per week; annual; from Wilson Fox, A. (1903). "Agricultural Wages in England and Wales During the Last Fifty Years," Journal of the Royal Statistical Society 66(2) pp. 273-359 and Appendix II, pp. 331-332.

1902-1914: Bowley and Wood's index of average agricultural wages, England and Wales, in a normal week; annual index $(1891=100)$; taken from Mitchell, B. R. (1988). British Historical Statistics. Cambridge: Cambridge University Press, pp. 158-159; original source: Bowley, A. L. (1937). Wages and Income Since 1860. Cambridge.

1914-1920: Weekly wage rate in agriculture, England and Wales, in July; annual index (July $1914=100$ ); taken from Mitchell (1988), p. 160; original source: Bowley, A. L. (1921). Prices and Wages in the United Kingdom, 1914-1920. Oxford: Oxford University Press.

1920-1936: Weekly wage rate in agriculture, England and Wales; annual index $(1924=100)$; taken from Mitchell (1988), p. 160; original source: Ramsbottom, E. C. (1935). "The Course of Wage Rates in the United Kingdom, 1921-34," Journal of the Royal Statistical Society XCVIII and similar article for 1934-1937 in ibid.

\section{Nominal Farm Land Rents 1500-1936 $(1900=100)$}

Index $A$

1500-1831: Land rental values, England average, $£ /$ acre; from Clark, G. (December 2002). "Land Rental Values and the Agrarian Economy: England and Wales, 1500-1912," European Review of Economic History 6(3), pp. 281-308, Table 8; values are given for 1500-39 (taken to be 1520), 1540-59 (1550), 1560-79 (1570) and 1580-99 (1590); reported by decade for the 17th century; reported at 5 yearly intervals from 1700 onwards; interpolated geometrically to get annual; rents are assumed constant from 1500-1520, in line with the data on land and farmhouse rental values in Clark, G. (October 2001). "The Secret History of the Industrial Revolution," Mimeo, Table 2, p. 15; and also in line with the data in Allen, R. C. (February 1988). "The Price of Freehold Land and the Interest Rate in the 
Seventeenth and Eighteenth Centuries," Economic History Review XLI (1), pp. 3350, discussed below under Index C.

1831-1870: Annual; from Thompson, J. (December 1907). "An Inquiry into the Rent of Agricultural Land in England and Wales during the Nineteenth Century," Journal of the Royal Statistical Society, LXX, Appendix, Table A, p. 612.

1871-1900: Annual; an unweighted average of Thompson (1907) and Rhee, H. A. (1949). The Rent of Agricultural Land in England and Wales. London: Central Landowners Association, Appendix Table 2, pp. 44-45.

1900-1936: Annual; Rhee (1949).

Index $B$

Alternative index 1690-1914: Annual; linked forwards and backwards to the rest of Index A above: Turner, M. E., J. V. Beckett, and B. Afton, (1997). Agricultural Rent in England 1690-1914. Cambridge: Cambridge University Press, Appendix Table A2.2, pp. 314-318.

\section{Index $C$}

Alternative index 1500-1831: South Midlands average rent, shillings per acre; by quarter century, interpolated geometrically; taken from Allen (1988), Table 2, p. 43.

1831-1936: As Index A above; annual.

Inter-Sectoral Terms of Trade, $\mathrm{Pa} / \mathrm{Pm}(1900=100)$ : Pa 1316-1938

1316-1450: Exeter wheat; annual; from Mitchell B. R., and P. Deane, (1962). Abstract of British Historical Statistics. Cambridge: Cambridge University Press, pp. 484-486.

1450-1640: "Average - all agricultural products," including grains, other arable crops, livestock and animal products; reported decadal, interpolated geometrically to get annual; from J. Thirsk (ed.) (1967). The Agrarian History of England and Wales, Volume IV: 1500-1640. Cambridge: Cambridge University Press, Table XIII, p. 862.

1640-1749: "Average - all agricultural products," including grains, other field crops, livestock and animal products; reported decadal, interpolated geometrically to get annual; from J. Thirsk (ed.) (1985). The Agrarian History of England and Wales, Volume V: 1640-1750. Cambridge: Cambridge University Press, Table XII, p. 856.

1749-1805: Wheat; reported decadal, interpolated geometrically to get annual; from Deane P. and W. A. Cole (1962). British Economic Growth 1688-1959, 2nd edn. Cambridge: Cambridge University Press, Table 23, p. 91. 
1805-1913: Total agricultural products; annual; from Mitchell and Deane (1962), pp. 471-473.

1913-1938: Total food; annual; from Mitchell and Deane (1962), p. 475.

Inter-Sectoral Terms of Trade, $\mathrm{Pa} / \mathrm{Pm}(1900=100)$ : $\mathrm{Pm} 1450-1938$

1450-1640: "Industrial products"; reported decadal, interpolated geometrically to get annual; from Thirsk (1967), Table XIII, p. 862.

1640-1749: "Industrial products"; reported decadal, interpolated geometrically to get annual; from Thirsk (1985), Table XII, p. 856.

1749-1796: "Other prices" (equals unweighted average of Schumpeter's producer goods); annual; from Deane and Cole (1962), Table 23, p. 91.

1796-1938: Price indices of merchandise exports (equals Imlah and Board of Trade, linked on 1913); from Mitchell and Deane (1962), pp. 331-332.

\section{Land/Labor Ratios $(1900=100)$ : Total Economy-Wide Labor Force 1500-1940}

Post-1840

1841-1951: "Total occupied," males and females; reported for census dates, interpolated geometrically to get annual (including the missing years 1932-1936); from Mitchell and Deane (1962), pp. 60-61.

Pre-1841

Labor force or population age distribution estimates do not exist for the period prior to the late 18th century. Thus, we simply link the population totals up to 1841 with the economy-wide labor force totals 1841-1936 (e.g., we assume the 1841 labor participation rate was constant between 1560 and 1840, and at the 1841 rate). Population 1541-1841: England; annual; from Wrigley, E. A. and R. S. Schofield. (1981). The Population History of England, 1541-1871. Cambridge: Cambridge University Press, Table A3.3, pp. 531-534.

Population 1500-1541: Assumes that growth was at the rate suggested by Wrigley and Schofield (1981), p. 737.

Land/Labor Ratios $(1900=100)$ : Land in Agriculture 1500-1940

Post-1866

1867-1936: Acreage in crops; Great Britain; annual: from Mitchell and Deane (1962), pp. 78-79. 
Pre- 1867

In his seminal piece on population in pre-industrial England, Ronald D. Lee ("Population in Preindustrial England: An Econometric Analysis," Quarterly Journal of Economics 87(4), pp. 581-607) quotes Postan to justify his assumption of a constant farm land endowment: "By 1066 the occupation of England by the English had gone far enough to have brought into cultivation ... most of the area known to have been occupied in later centuries of English history." (Postan, M. M. (1966). "Medieval Agrarian Society in Its Prime" in H. J. Habakkuk and M. M. Postan (eds.), Cambridge Economic History of Europe, Vol. I, 2nd edn., Chapter VII, Part 7. Cambridge: Cambridge University Press, pp. 567-568. We make the same assumption.

\section{Manufacturing Productivity $(1900=100)$}

1869-1936: Manufacturing output divided by manufacturing employment; annual (with interpolations between 1913 and 1920); taken from Broadberry, S. N. (1997). The Productivity Race: British Manufacturing in International Perspective, 1850-1990 Cambridge: Cambridge University Press, Appendix 3, pp. 42-44.

1700-1869: Industrial production divided by industrial labor force. Industrial production taken from Crafts, N. F. R. and C. K. Harley. (November 1992). "Output Growth and the British Industrial Revolution: A Restatement of the Crafts-Harley View," Economic History Review XLV(4), pp. 703-730, 'revised best guess', Table A3.1, pp. 725-727; annual. Industrial labor force based on applying estimates of the industrial share of the labor force to the annual labor force estimates above. Crafts, N. F. R. (1985). British Economic Growth During the Industrial Revolution. Oxford: Clarendon Press, Table 3.6, pp. 62-63, gives estimates of the industrial share of the male labor force for 1700, 1760, 1800, 1840 and 1870. Data for intervening years are generated by geometric interpolation. The procedure assumes that the industrial share of the female labor force was similar to that of the male labor force.

1500-1700: Non-agricultural output divided by non-agricultural labor force. Based on data given in Clark (October 2001). Data on nominal GDP are taken from his Table 3, pp. 19-20, and are deflated using the GDP deflator in his Table 7, pp. 30-31. Real GDP is then divided into its agricultural and non-agricultural components by assuming that these are proportional to the wage bills in the two sectors (which is equivalent to assuming that the ratio of the average products in the two sectors is equal to the ratio of the marginal products in the two sectors). The ratio of the wage bill in the two sectors is derived using the data on sectoral wages and the farm share of the labor force, given in Table 1, pp. 8-9 (and, following Clark, p. 7, letting the non-farm wage be the average of urban craftsman and laborer wages). The resulting output series is divided by the non-agricultural labor force, derived using Clark's farm share of the labor force and the annual labor force series described above. 


\section{Total Factor Productivity in Agriculture}

1500-1911: Clark (forthcoming 2002), Table 9, p. 48; data for 1520, 1550, 1570, 1590; decadal from 1605; interpolated to get annual. We assume that the $1520-1550$ growth rate applied to $1500-1520$.

1911-1936: Derived assuming constant growth rate of $0.4 \%$ p. a. $1911-1924 ; 2.1 \%$ p. a. 1924-1936. Based on Matthews, R. C. O., C. H. Feinstein, and J. C. Odling-Smee. (1982). British Economic Growth 1856-1973 (Stanford, CA: Stanford University Press), Table L.2, p. 607 and Table I.3, p. 598. The calculation assumes that the 1899-1913 growth rate persisted until 1924.

\section{References}

Acemoglu, D., S. Johnson, and J. Robinson. (2002). "The Rise of Europe: Atlantic Trade, Institutional Change and Economic Growth," CEPR Discussion Paper 3712, London: CEPR.

Allen, R. C. (1988). "The Price of Freehold Land and the Interest Rate in the Seventeenth and Eighteenth Centuries," Economic History Review 41 (February), 33-50.

Allen, R. C. (1992). Enclosure and the Yeoman. Oxford: Clarendon Press.

Bairoch, P. (1989). "European Trade Policy, 1815-1914," in Mathias P., and Pollard S. (eds.), The Cambridge Economic History of Europe. Vol. III. Cambridge: Cambridge University Press.

Blattman, C., M. A. Clemens, and J. G. Williamson. (2002). "Who Protected and Why? Tariffs the World Around 1870-1937," paper presented to the Conference on the Political Economy of Globalization. Trinity College, Dublin (August 29-31).

Clark, G. (n.d.). "The Long March of History: Farm Laborers' Wages in England 1208-1850," mimeo, Davis: University of California.

Clark, G. (2001). "Farm Wages and Living Standards in the Industrial Revolution: England, 16701850," Economic History Review 54 (August), 477-505.

Coatsworth, J. H., and J. G. Williamson. (2004). "The Roots of Latin American Protectionism: Looking Before the Great Depression," in Estevadeordal, A., D. Rodrik, A. Taylor, and A. Velasco (eds.), FTAA and Beyond: Prospects for Integration in the Americas. Cambridge, MA: Harvard University Press.

Crafts, N. F. R. (1985). British Economic Growth During the Industrial Revolution. Oxford: Clarendon Press.

Crafts, N. F. R. (1994). "The Industrial Revolution," in R. Floud and D. McCloskey (eds.), The Economic History of Britain Since 1700, Vol. 1. Cambridge: Cambridge University Press.

Crafts, N. F. R., and C. K. Harley. (1992). "Output Growth and the Industrial Revolution: A Restatement of the Crafts-Harley View," Economic History Review 45(4), 703-730.

Dobb, M. (1946). Studies in the Development of Capitalism. London: Routledge and Kegan Paul.

Flam, H., and M. J. Flanders (1991). Heckscher-Ohlin Trade Theory. Cambridge, MA: MIT Press.

Findlay, R. (1982). "Trade and Growth in the Industrial Revolution," in Kindleberger, C. P., and G. Di Tella (eds.), Economics in the Long View: Essays in Honor of W.W. Rostow New York: New York University Press.

Findlay, R. (1990). "The 'Triangular Trade' and the Atlantic Economy of the Eighteenth Century: A Simple General-Equilibrium Model," Essays in International Finance 177, International Finance Section, Department of Economics, Princeton University.

Findlay R., and K. H. O'Rourke. (2002). "Commodity Market Integration 1500-2000," in Bordo, M., A. M. Taylor, and J. G. Williamson (eds.), Globalization in Historical Perspective Chicago: University of Chicago Press.

Galor, O., and A. Mountford. (2002). "Why are a Third of People Indian and Chinese? Trade, Industrialization and Demographic Transition," CEPR Discussion Paper 3136, London: CEPR. 
Galor, O., and D. N. Weil. (2000). "Population, Technology, and Growth: From Malthusian Stagnation to the Demographic Transition and Beyond," American Economic Review 90 (September): 806828.

Goodfriend M., and J. McDermott. (1995). "Early Development," American Economic Review 85 (March), 116-133.

Hansen, G. D., and E. C. Prescott. (2002). "Malthus to Solow," American Economic Review 92 (September), 1205-1217.

Harley, C. K., (1988). "Ocean Freight Rates and Productivity, 1740-1913: The Primacy of Mechanical Invention Reaffirmed," Journal of Economic History 48 (December), 851-876.

Harley, C. K., and N. F. R. Crafts. (2000). "Simulating the Two Views of the British Industrial Revolution," Journal of Economic History 60 (September), 819-841.

Hoffmann, W. G. (1955). British Industry, 1700-1950. Oxford: Basil Blackwell.

Jacks, D. (2000). "Market integration in the North and Baltic Seas, 1500-1800," LSE Working Papers in Economic History 55/00, London School of Economics, London (April).

Jones, C. I. (2001). "Was the Industrial Revolution Inevitable? Economic Growth Over the Very Long Run," Advances in Macroeconomics 1(2), article 1.

Jones, R. W. (1971). "A Three-Factor Model in Theory, Trade, and History," in Bhagwati, J. et al. (eds.), Trade, Balance of Payments, and Growth. Amsterdam: North-Holland.

Lucas, R. (1999). The Industrial Revolution: Past and Future, mimeo. University of Chicago, Department of Economics.

MacKinnon, J. G. (1996). "Numerical Distribution Functions for Unit Root and Cointegration Tests," Journal of Applied Econometrics 11(6) November-December: 601-618.

Malthus, T. R., (1826). An Essay on the Principle of Population. Cambridge: Cambridge University Press.

Mancall, P. C., J. L. Rosenbloom, and T. Weiss. (2001). "Slave Prices and the South Carolina Economy, 1722-1809," Journal of Economic History 61 (September), 616-639.

Mancall, P. C., J. L. Rosenbloom, and T. Weiss. (2002). "Agricultural Labor Productivity in the Lower South, 1720-1800", Explorations in Economic History 39 (October): 390-424.

Marx, K. (1867). Capital, trans. S. Moore and E. Aveling, 3 Vols., 1867-1894, Vol. i. New York: Random House, 1906.

Mitchell, B. R. (1988). British Historical Statistics. Cambridge: Cambridge University Press.

Mokyr, J. (1977). "Demand vs. Supply in the Industrial Revolution," Journal of Economic History 37, 981-1008.

Mokyr, J. (1990). The Lever of Riches: Technological Creativity and Economic Progress. New York: Oxford University Press

Morgan, K. (2000). Slavery, Atlantic Trade and the British Economy 1660-1800. Cambridge: Cambridge University Press.

North, D. C. (1958). "Ocean Freight Rates and Economic Development 1750-1913," Journal of Economic History 18 (December): 538-555.

O'Brien, P. K. (1982). "European Economic Development: The Contribution of the Periphery," Economic History Review 35 (February), 1-18.

O'Brien, P. K., and S. L. Engerman. (1991). "Exports and the Growth of the British Economy from the Glorious Revolution to the Peace of Amiens," in Solow B. L. (ed.), Slavery and the Rise of the Atlantic System. Cambridge: Cambridge University Press, pp. 177-209.

O'Rourke, K. H. (1997). "The European Grain Invasion, 1870-1913," Journal of Economic History 57 (December), 775-801.

O'Rourke K. H., and R. Sollis. (ongoing). "Globalisation, endowments and factor prices in England 1500-1936," mimeo.

O'Rourke, K. H., A. M. Taylor, and J. G. Williamson. (1996). "Factor Price Convergence in the Late Nineteenth Century," International Economic Review 37 (August), 499-530.

O'Rourke, K. H., and J. G. Williamson. (1994). "Late 19th Century Anglo-American Factor Price Convergence: Were Heckscher and Ohlin Right?" Journal of Economic History 54 (December), 892-916.

O'Rourke, K. H., and J. G. Williamson. (1999). Globalization and History: The Evolution of a 19th Century Atlantic Economy, Cambridge, MA: MIT Press. 
O'Rourke, K. H., and J. G. Willamson (2002a). “After Columbus: Explaining the Global Trade Boom 1500-1800," Journal of Economic History 62 (March), 1-31.

O'Rourke, K. H., and J. G. Willamson (2002b). "When Did Globalization Begin?" European Review of Economic History 6 (April), 23-50.

O'Rourke, K. H. (2002c). "The Heckscher-Ohlin Model Between 1400 and 2000: When It Explained Factor Price Convergence, When It Did Not, and Why,' in Findlay, R., L. Jonung, and M. Lundahl (eds.), Bertil Ohlin: A Centennial Celebration. Cambridge, MA.: MIT Press.

Rhee, H. A. (1949). The Rent of Agricultural Land in England and Wales. London: Central Landowners Association.

Stokey, N. L. (2001). "A Quantitative Model of the British Industrial Revolution, 1780-1850," Carnegie-Rochester Conference Series on Public Policy 55. Amsterdam: North-Holland, pp. 55-109.

Temin, P. (1997). "Two Views of the British Industrial Revolution," Journal of Economic History 57 (March), 63-82.

Thompson, R. J. (1907). “An Inquiry into the Rent of Agricultural Land in England and Wales during the Nineteenth Century," Journal of the Royal Statistical Society 70 (December), 587-616.

U. S. Department of Commerce. (1975). Historical Statistics of the United States. Washington, DC: USGPO.

Williamson, J. G. (1990). "The Impact of the Corn Laws Just Prior to Repeal," Explorations in Economic History 27 (April), 123-156.

Williamson, J. G. (2002). "Land, Labor and Globalization in the Third World 1870-1940," Journal of Economic History 62(1 March), 55-85.

Williamson, J. G. (2005). "Explaining World Tariffs 1870-1938: Stolper-Samuelson, Strategic Tariffs and State Revenues," in Findlay, R., R. Henriksson, H. Lindgren, and M. Lundahl (eds.), Eli F. Heckscher, 1879-1952: A Celebratory Symposium Cambridge, MA: MIT Press, forthcoming.

Williamson, J. G., and P. H. Lindert. (1980). American Inequality: A Macroeconomic History. New York: Academic Press. 